\title{
A model for determining the locations of electric vehicles' charging stations in Istanbul
}

\section{İstanbul'da elektrikli araç şarj istasyonlarının konumlandırılması için bir model}

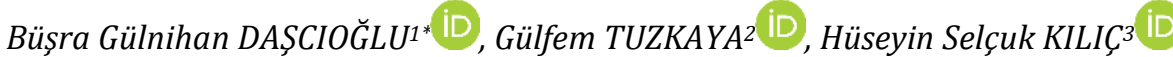 \\ 1,2,3 Department of Industrial Engineering, Engineering Faculty, Marmara University, İstanbul, Turkey. \\ busradascioglu@gmail.com,gulfem.tuzkaya@marmara.edu.tr, huseyin.kilic@marmara.edu.tr
}

\section{Abstract}

The studies about Electric Vehicles (EV) have gained importance and increased in the last years depending on the environmental concerns of the classic transportation systems. One of the problems to consider at this point is locating the proper points of electric charging stations for EVs. The primary objective of this research is to locate the electric charging stations in Istanbul considering the flow of the paths. The locations of electric charging stations are determined by using a mathematical model based on the flow-refuelling location model with the aim of maximizing the captured flow. The mathematical model is run for various values of " $p$ " and the optimum locations are obtained.

Keywords: Flow-refuelling location model, Assignment problem, Electric vehicles, Electric charging stations

\section{Introduction}

In recent years, plug-in electric vehicles are receiving attention since they provide good alternatives for liquid fossil fuel problems. $\mathrm{CO}_{2}$ emission consumption is calculated around $4 \%$ through the years of 2014 and 2016 [1].

According to the survey of Global Carbon Project, Figure 1 shows $\mathrm{CO}_{2}$ emission from fossil fuels over the last 59 years [2] In addition to this gloomy picture, there are also the warnings of the energy sector about the losses in energy [3]. However, researchers prepare studies which aim to decrease carbon emissions by increasing the usage of EVs to regulate the source of vehicles using fossil fuel.

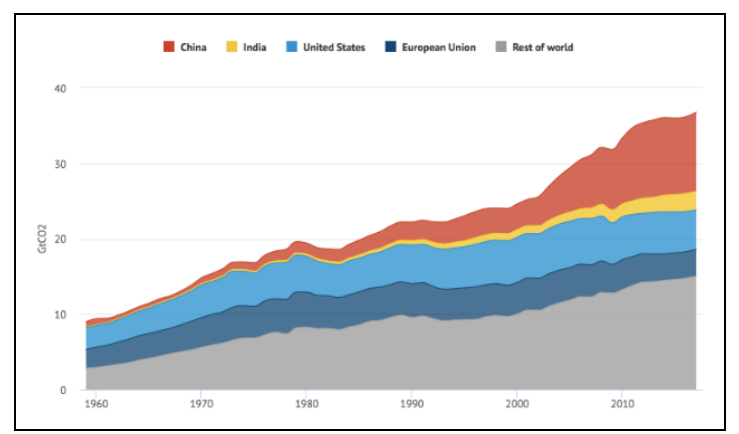

Figure 1: The amount of $\mathrm{CO}_{2}$ emissions of countries from using fossil fuels, 1959-2017 [2].

Type of the battery directly affects the plug-in electric vehicles' driving performance and cost of the path [4]. Researchers have $\ddot{0} \mathrm{z}$

Klasik ulaștırma sistemlerinin cevresel kaygıları göz önünde bulundurulduğunda, elektrikli araçlarla (EA) ilgili çalışmalar önem kazanmıș ve son yıllarda sayıca artmıștır. Bu noktada ele alınması gereken sorunlardan biri EA'lar için şarj istasyonlarının uygun yerlerinin belirlenmesidir. Bu çalıșmanın temel amacl, İstanbul'daki elektrik sarj istasyonlarına iliskin en uygun konumları yolların akısın değerlendirmeye alarak bulmaktır. Şarj istasyonlarının konumları, yolların kapsanan akısin maksimize etmeyi amaclayan akıs-yakıt ikmal lokasyon modeline dayanan bir model kullanılarak belirlenmiștir. Matematiksel model farkl " $p$ " değerli için çözülmüș ve en iyi lokasyonlar belirlenmiştir.

Anahtar kelimeler: Akış-yakıt ikmal lokasyon modeli, Atama problemi, Elektrikli araçlar, Elektrik șarj istasyonları

been examining these special types of vehicles for reducing the natural damage nevertheless the alternative fuel vehicles and normal vehicle types are not fully overused [5]. Since the current infrastructure is insufficient and the cost of establishing new electric charging stations is high, the advancements in electric vehicles in developing countries such as Turkey occur slowly. Table 1 shows electric and hybrid automobile sales numbers [6] in Turkey. For instance, in the first 9 months of 2019, 7562 electric and hybrid automobiles are sold in Turkey.

Table 1: Electric and hybrid automobile sales numbers in Turkey [6].

\begin{tabular}{ccc}
\hline & Sales & Cumulative Sales \\
Near & Numbers & 225 \\
\hline 2015 & 225 & 1219 \\
2016 & 994 & 5747 \\
2017 & 4528 & 9778 \\
2018 & 4031 & 17340 \\
\hline
\end{tabular}

Due to increase in the usage level of electric vehicles, demand on the electric charging stations increases [7]. The primary challenge of EV charging technology industry is to determine the optimal capacitated and located electric charging stations [8]. There are four presumptions made for EVs charging necessities in Lee and Han's research (2017) [9]: driver selects the shortest route, at the beginning of the route, half of the battery is full, at the end of the route, the battery must not be less than half of the battery and finally the travel range is constant and deterministic. 
Electric charging station infrastructures are considered in two groups; urban developments which use node-based approach [10], this type of electric charging stations meets the demand when the vehicle is in the parking. Intercity developers on the other hand, meet demands of vehicles during long journeys and usually use flow-based development approach [11]. In intracity charging demand, the charging process is carried out at the end of the trip of vehicle; in intercity, the process interrupts the trip of the vehicle [12].

In this study, a flow-refuelling location model is applied. The study is motivated by the fact that the sales rate of alternative vehicles is increasing day-by-day but there are not enough stations to cover the demand. To our knowledge, this solution methodology is not applied for Istanbul before. This study emphasizes the authorized electric charging station problem for plug-in electric vehicles in Istanbul. The goal is to maximize the captured flow of all paths between districts of Anatolian part of Istanbul. The main contributions of this paper are as follows:

1. This research extends the previous articles and is the first paper that considers all districts in Anatolian part of Istanbul,

2. This study is the first paper that uses flow-refuelling location problem for the case of Istanbul.

The first part of the article deals with the fundamentals of the methods, in the second part, an application is given to investigate the effectiveness of the suggested approach. In the last part, the results and conclusions are presented.

\section{Literature review}

Determining the locations of charging station for EVs is the most important part of EV studies, therefore most of the studies consider finding the proper locations of charging stations. There are several different solution methods in this area.

The authors in [7], designed electric charging station network in Turkey by using capacitated $p$-median location model. The model aimed to maximize the company managers' preference scores. The capacity data was gathered from managers through maximum number of districts and maximum possible customer queue of the location as constraints. In another research, authors [13], proposed three methods for determining locations; a multi-period optimization model based on flowrefueling location model and two myopic methods. They considered multi-period plan for Korean Expressways as a case study. Performance analysis was made by comparing the results of these methods. In another study, bus network of Stockholm was considered for solving the location selection problem of electric charging stations for electric buses. Authors presented MILP model. The model aimed to minimize transportation cost of bus network [14]. The authors in [15], implemented two-step model by using the data of the flow of EVs and the road network. First, the model calculated the required number of electric charging stations and located the stations by considering road network of EVs. This method was tested in Italian highway network.

The authors in [16], implemented multi-criteria decisionmaking structure for locating charging stations. Criteria were selected by extended sustainability theory and by using fuzzy Delphi method. In another article, researchers [8], aimed to solve the optimal siting of electric charging stations problem in Allahabad, India. For solving the mentioned problem, authors implemented a hybrid algorithm based on genetic and particle swarm optimization algorithms. After gathering the results, the infrastructure was tested in simulation by real time system. Another multi-criteria method was implemented by researchers in [12], for solving the problem in Hungary. Weighted multi-criteria decision making model was utilized for considering the existing stations and installing new stations. The criteria were selected as demographic, economic, environmental and transportation based.

In [17], researchers aimed to locate EVCS in three districts of Istanbul by using fuzzy AHP methodology. Spatial geographic information systems were used for gathering the data and with the criteria ranks of fuzzy AHP, a GIS based map layer was created. To solve location problem of EVCS in USA, authors extended the set coverage model by adding distance satisfaction function. The main aim of algorithm was to meet the customer demand by considering the cost constraints and battery life of an EV [18]. In a major advance in 2018, researchers proposed geographic information system based multi-criteria decision algorithm for selecting the proper locations of charging stations in Ankara, Turkey. After determining criteria and sub-criteria, fuzzy AHP and TOPSIS methodologies were used by considering geographic information map. The results presented suggested alternative locations [19].

In 2019, Ju et al. [20] used multi criteria decision making methodology and extended grey relation projection algorithm for ranking the possible locations for EVCS in Beijing, China. After determining main and sub-criteria, fuzzy AHP and grey relational projection algorithms were used in order to determine the possible locations' ranks. A data-driven and particle swarm optimization based heuristic algorithm was developed in order to locate the EVCS with consideration of round trips [21]. Improved Whale Optimization Algorithm was modeled by the researchers of [22], for locating EVCS by considering service risk capacity constraints. The MILP model and improved Whale Optimization Algorithm were compared as conclusion. Both models were aimed to reduce social costs without risking the service capacity. A recent paper was presented by authors of [23], considering the problem of locating fast-charging EVS to the European highway network of France, Germany, the Benelux countries, Switzerland, Austria, Denmark, the Czech Republic, and Poland. Passenger car trips in Europe data were solved by efficient flow-refueling location model. The main contribution of the research was considering the profitability of fast charging stations. Finally, an extended TOPSIS methodology was used for finding the suitable locations of electric charging stations in Istanbul by Dascioglu et al. [24].

\section{Implemented methodology}

In this section, mathematical representation of flow-refuelling location model ([25]-[27]) is explained.

The flow capturing problem is originally designed and used for facility location problem and it is one of the most important discrete location theory problems. The flow-refuelling location model aims to decide the locations of the facilities or stations in our situation and allocate the demand points to one or more stations by considering the flow of paths' between locations.

q: index of OD pairs (the shortest paths for each pair),

Q: set of all OD pairs,

$\mathrm{f}_{\mathrm{q}}$ : flow volume on the OD pair $\mathrm{q}$ 
k: index of facility locations,

K: set of all potential facility locations,

p: the number of facilities to be located,

$\mathrm{h}$ : index of facility combinations,

$\mathrm{H}$ : set of all potential facility combinations.

$$
\begin{aligned}
y_{q} & =\left\{\begin{array}{lc}
1, & \text { if } f_{q} \text { is captured } \\
0, & \text { otherwise }
\end{array}\right. \\
x_{k} & = \begin{cases}1, & \text { if a facility is located at } k \\
0, & \text { otherwise }\end{cases} \\
v_{h} & = \begin{cases}1, & \text { if all facilities in combination } h \text { are open } \\
0, & \text { otherwise }\end{cases} \\
a_{h k} & = \begin{cases}1, & \text { if facility } k \text { is in combination } h \\
0, & \text { otherwise }\end{cases} \\
b_{q h} & = \begin{cases}1, & \text { if facility combination } h \text { can refuel oD pair } q \\
0, & \text { otherwise }\end{cases}
\end{aligned}
$$

$$
\begin{aligned}
& \max Z=\sum_{q \in Q} f_{q} y_{q} \\
& \sum_{h \in H} b_{q h} v_{h} \geq y_{q} \quad \forall q \in Q \\
& a_{h k} x_{k} \geq v_{h} \\
& \forall h \in H ; k \in K \\
& \sum_{k \in K} x_{k}=p \\
& x_{k}, v_{h}, y_{q} \in\{0,1\} \\
& \forall k, h, q
\end{aligned}
$$

Objective function (1) aims to maximize the flow volume that can be refuelled. Constraint (2) prevents the capturing of path $q$, unless a suitable combination of facilities is selected. Constraint (3) ensures the opening of all facilities in a selected facility combination $h$. Constraint (4) ensures that the number of opened stations equals to $p$. Constraint (5) provides the binary constraints.

\section{Application of the methodology}

\begin{tabular}{|c|c|}
\hline No & Set of All Potential Stations \\
\hline 1 & Atașehir \\
\hline 2 & Beykoz \\
\hline 3 & Cekmeköy \\
\hline 4 & Kadıköy \\
\hline 5 & Kartal \\
\hline 6 & Maltepe \\
\hline 7 & Pendik \\
\hline 8 & Sancaktepe \\
\hline 9 & Ümraniye \\
\hline 10 & Üsküdar \\
\hline \multicolumn{2}{|r|}{ Table 3: Combination of facilities. } \\
\hline No & Set of All Potential Facility Combinations \\
\hline 1 & Atașehir-Kadıköy \\
\hline 2 & Ataşehir-Maltepe \\
\hline 3 & Ataşehir - Ümraniye \\
\hline 4 & Ataşehir-Üsküdar \\
\hline 5 & Beykoz-Çekmeköy \\
\hline 6 & Beykoz-Sancaktepe \\
\hline 7 & Beykoz-Ümraniye \\
\hline 8 & Beykoz-Üsküdar \\
\hline 9 & Çekmeköy-Sancaktepe \\
\hline 10 & Cekmeköy-Sile \\
\hline 11 & Çekmeköy-Ümraniye \\
\hline 12 & Kadıköy-Üsküdar \\
\hline 13 & Kadıköy-Maltepe \\
\hline 14 & Kartal-Maltepe \\
\hline 15 & Kartal-Pendik \\
\hline 16 & Kartal-Sancaktepe \\
\hline 17 & Kartal-Sultanbeyli \\
\hline 18 & Maltepe-Sancaktepe \\
\hline 19 & Maltepe-Sultanbeyli \\
\hline 20 & Sancaktepe-Sultanbeyli \\
\hline 21 & Sancaktepe-Tuzla \\
\hline 22 & Ataşehir-Ümraniye-Üsküdar \\
\hline 23 & Beykoz-Çekmeköy-Sancaktepe \\
\hline 24 & Kadlköy-Maltepe-Kartal \\
\hline 25 & Ataşehir-Ümraniye-Üsküdar-Kadıköy \\
\hline 26 & Beykoz-Çekmeköy-Sancaktepe-Sultanbeyli \\
\hline
\end{tabular}

The suggested approach is applied on nine different policies considering the number of charging station locations $(p)$ from 2 to 10 . Table 2 shows the potential station locations $(k)$ and Table 3 shows the combination of facilities $(h)$. While determining the combination of facilities, it is benefited from the geographical locations of the districts.

\begin{tabular}{|c|c|c|c|c|c|c|c|c|c|c|c|c|c|}
\hline District & 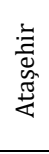 & $\begin{array}{l}\text { No } \\
\text { 产 } \\
\text { Ф }\end{array}$ & 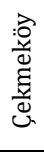 & 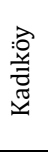 & 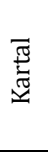 & $\frac{\stackrel{\Delta}{\Delta}}{\frac{\pi}{\pi}}$ & 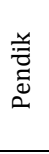 & 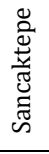 & 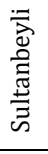 & $\stackrel{0}{\ddot{\infty}}$ & $\underset{F}{\stackrel{\pi}{N}}$ & 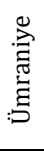 & 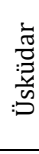 \\
\hline Ataşehir & - & 24 & 34 & 9 & 17 & 11 & 33 & 29 & 14 & 63 & 26 & 7 & 14 \\
\hline Beykoz & 24 & - & 24 & 29 & 37 & 34 & 60 & 35 & 34 & 73 & 47 & 22 & 26 \\
\hline Çekmeköy & 34 & 24 & - & 38 & 33 & 27 & 43 & 14 & 21 & 36 & 33 & 29 & 36 \\
\hline Kadıköy & 9 & 29 & 38 & - & 19 & 13 & 20 & 24 & 18 & 63 & 30 & 12 & 11 \\
\hline Kartal & 17 & 37 & 33 & 19 & - & 13 & 7 & 21 & 18 & 60 & 17 & 22 & 27 \\
\hline Maltepe & 11 & 34 & 27 & 13 & 13 & - & 16 & 16 & 11 & 56 & 27 & 19 & 20 \\
\hline Pendik & 33 & 60 & 43 & 20 & 7 & 16 & - & 29 & 23 & 71 & 16 & 27 & 29 \\
\hline Sancaktepe & 29 & 35 & 14 & 24 & 21 & 16 & 29 & - & 10 & 41 & 21 & 19 & 28 \\
\hline Sultanbeyli & 14 & 34 & 21 & 18 & 18 & 11 & 23 & 10 & - & 50 & 16 & 20 & 25 \\
\hline Şile & 63 & 73 & 36 & 63 & 60 & 56 & 71 & 41 & 50 & - & 63 & 57 & 63 \\
\hline Tuzla & 26 & 47 & 33 & 30 & 17 & 27 & 16 & 21 & 16 & 63 & - & 32 & 36 \\
\hline Ümraniye & 7 & 22 & 29 & 12 & 22 & 19 & 27 & 19 & 20 & 57 & 32 & - & 12 \\
\hline Üsküdar & 14 & 26 & 36 & 11 & 27 & 20 & 29 & 28 & 25 & 63 & 36 & 12 & - \\
\hline
\end{tabular}

The objective of the article is to determine the locations of electric charging stations. Optimum locations of the districts in the Anatolian side of Istanbul are obtained by a flow capturing method based on the flows between locations and possible electric charging station locations.

Table 2: Potential station locations.

Paths were created by considering the minimum driving range of a typical electric vehicle. The electric vehicle can travel $40 \mathrm{~km}$ with low electric load. In Table 4, the distance matrix of districts is shown for the Anatolian part of Istanbul.

Table 4: Distance matrix of districts. 
The data is gathered from General Directorate for Highways department [28]. Table 5 shows the paths of OD pairs and flows of the paths $\left(f_{q}\right)$. The flows are assumed to be proportional with the number of gas stations on the paths. Hence, relative path flow scores are obtained based on the path having the minimum number of gas stations.

Figure 2 shows a sample path of (number 14) Beykoz Çekmeköy-Sancaktepe-Sultanbeyli on the map. The flow score of this path (15) is obtained by getting the sum of the flow scores between its nodes which are given as follows:

Beykoz-Çekmeköy: 6

Çekmeköy-Sancaktepe: 5

Sancaktepe-Sultanbeyli: 4
The mathematical model is run for the nine different $p$ values and the optimum solutions are obtained. The results of the applied model are shown in Table 6. The gap ratio (GR) is computed considering the deviation from the maximum captured flow score among the solutions of all $p$ values. For instance, the GR for $p=2$ is obtained via the following calculations.

$\mathrm{GR}(\mathrm{p}=2)=(358-165) / 358=53.91 \%$

When the GR values are analyzed, it is concluded that there is no significant improvement for the $p$ value bigger than 6 . Hence, it does not seem reasonable to establish the system with more than 6 electric charging stations in the initial stage.

Considering the result of $p=2$ case, the map of one of the two selected stations, Kartal, and the captured paths are shown in Figure 3.

Table 5: Determined OD pairs and the flows of pairs $\left(f_{q}\right)$

\begin{tabular}{|c|c|c|c|}
\hline No. & Path Code & Paths & Path Flow Score $\left(f_{q}\right)$ \\
\hline 1 & P1 & Atașehir - Ümraniye & 9 \\
\hline 2 & P2 & Beykoz - Çekmeköy & 6 \\
\hline 3 & P3 & Çekmeköy - Şile & 5 \\
\hline 4 & $\mathrm{P} 4$ & Kadıköy - Üsküdar & 8 \\
\hline 5 & P5 & Kartal - Pendik & 12 \\
\hline 6 & P6 & Maltepe - Sultanbeyli & 8 \\
\hline 7 & P7 & Sancaktepe - Tuzla & 10 \\
\hline 8 & P8 & Ataşehir - Ümraniye - Üsküdar & 13 \\
\hline 9 & P9 & Beykoz - Çekmeköy - Sancaktepe & 11 \\
\hline 10 & $\mathrm{P} 10$ & Kadıköy - Maltepe - Kartal & 12 \\
\hline 11 & $\mathrm{P} 11$ & Pendik - Tuzla - Sultanbeyli & 17 \\
\hline 12 & $\mathrm{P} 12$ & Ataşehir - Ümraniye - Üsküdar - Kadıköy & 17 \\
\hline 13 & P13 & Üsküdar - Ümraniye - Çekmeköy - Şile & 14 \\
\hline 14 & P14 & Beykoz - Çekmeköy - Sancaktepe - Sultanbeyli & 15 \\
\hline 15 & P15 & Maltepe - Kartal - Pendik - Tuzla & 21 \\
\hline 16 & P16 & Atașehir - Ümraniye - Üsküdar - Kadıköy - Maltepe & 21 \\
\hline 17 & P17 & Beykoz - Çekmeköy - Sancaktepe - Sultanbeyli - Tuzla & 20 \\
\hline 18 & P18 & Ataşehir - Ümraniye - Üsküdar - Kadıköy - Maltepe - Sultanbeyli & 25 \\
\hline 20 & $\mathrm{P} 20$ & Beykoz - Üsküdar- Ümraniye - Ataşehir - Kadıköy - Maltepe - Kartal & 27 \\
\hline 21 & $\mathrm{P} 21$ & Beykoz - Cekmeköy - Sancaktepe - Sultanbeyli - Maltepe - Kartal - Pendik & 31 \\
\hline 22 & P22 & Beykoz - Çekmeköy - Sancaktepe - Sultanbeyli - Maltepe - Kartal - Tuzla & 28 \\
\hline
\end{tabular}

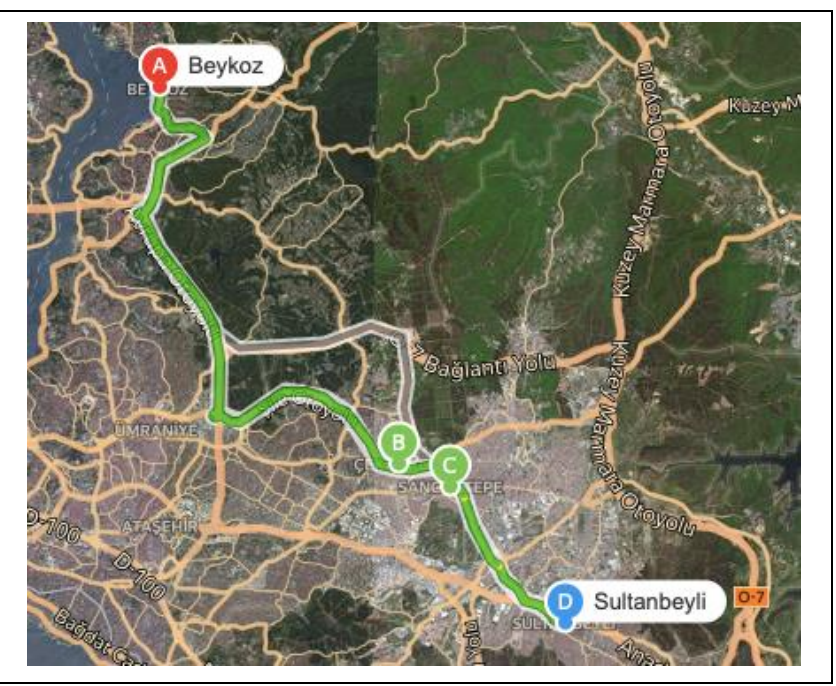

Figure 2: A sample path between Beykoz-Sultanbeyli.

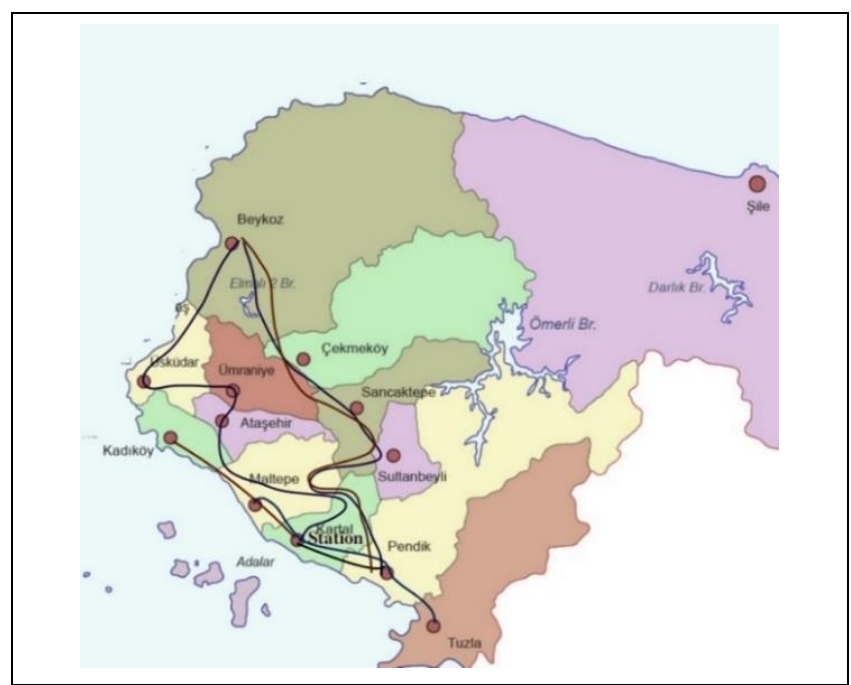

Figure 3: A sample path of selected station Kartal and covered paths. 
Table 6: Results of the applied model.

\begin{tabular}{|c|c|c|c|c|}
\hline$p$ & Station & Covered Paths & Total Flow & GR (\%) \\
\hline \multirow{2}{*}{2} & Kartal & P5; P10; P15; P20; P21; P22 & \multirow{2}{*}{165} & \multirow{2}{*}{$53.91 \%$} \\
\hline & Sancaktepe & P7; P14; P17; P19; P21; P22 & & \\
\hline \multirow{3}{*}{3} & Beykoz & P2; P9; P14; P17; P19; P20; P21; P22 & \multirow{3}{*}{258} & \multirow{3}{*}{$27.93 \%$} \\
\hline & Çekmeköy & P2; P3; P9; P13; P14; P17; P19; P21; P22 & & \\
\hline & Sancaktepe & P7; P9; P14; P17; P19; P21; P22 & & \\
\hline \multirow{4}{*}{4} & Beykoz & P2; P9; P14; P17; P19; P20; P21; P22 & \multirow{4}{*}{291} & \multirow{4}{*}{$18.72 \%$} \\
\hline & Çekmeköy & P2; P3; P9; P13; P14; P17; P19; P21; P22 & & \\
\hline & Kartal & P5; P15; P20; P21; P22 & & \\
\hline & Sancaktepe & P7; P9; P14; P17; P19; P21; P22 & & \\
\hline \multirow{5}{*}{5} & Beykoz & P2; P9; P14; P17; P19; P20; P21; P22 & \multirow{5}{*}{311} & \multirow{5}{*}{$13.13 \%$} \\
\hline & Çekmeköy & P2; P3; P5; P6; P7; P9; P10; P12; P13; P14; P15; P16; P17; P18; P19; P20; P21; P22 & & \\
\hline & Kartal & P5; P10; P15; P20; P21; P22 & & \\
\hline & Maltepe & P6; P10; P15; P16; P18; P20; P21; P22 & & \\
\hline & Sancaktepe & P7; P9; P14; P17; P19; P21; P22 & & \\
\hline \multirow{6}{*}{6} & Atașehir & P1; P8; P12; P16; P18; P20 & \multirow{6}{*}{327} & \multirow{6}{*}{$8.66 \%$} \\
\hline & Çekmeköy & P3; P9; P13; P14; P17; P19; P21; P22 & & \\
\hline & Kartal & P5; P10; P15; P20; P21; P22 & & \\
\hline & Maltepe & P6; P10; P15; P16; P18; P20; P21; P22 & & \\
\hline & Sancaktepe & P7; P9; P14; P17; P19; P21; P22 & & \\
\hline & Ümraniye & P1; P8; P12; P13; P16; P18; P20 & & \\
\hline \multirow{7}{*}{7} & Atașehir & P1; P8; P12; P16; P17; P18; P20 & \multirow{7}{*}{333} & \multirow{7}{*}{$6.98 \%$} \\
\hline & Beykoz & P2; P9; P14; P17; P19; P20; P21; P22 & & \\
\hline & Çekmeköy & P2; P3; P9; P13; P14; P17; P19; P21; P22 & & \\
\hline & Kartal & P5; P10; P15; P20; P21; P22 & & \\
\hline & Maltepe & P6; P10; P15; P16; P18; P20; P21; P22 & & \\
\hline & Sancaktepe & P7; P9; P14; P17; P19; P21; P22 & & \\
\hline & Ümraniye & P1; P8; P12; P13; P16; P18; P20 & & \\
\hline \multirow{8}{*}{8} & Ataşehir & P1; P8; P12; P16; P18; P20 & & \\
\hline & Çekmeköy & P3; P9; P13; P14; P15; P17; P19; P21; P22 & & \\
\hline & Kadıköy & P4; P10; P12; P16; P18; P20 & & \\
\hline & Kartal & P5; P10; P15; P20; P21; P22 & 252 & \\
\hline & Maltepe & P6; P10; P15; P16; P18; P20; P21; P22 & 352 & $1.68 \%$ \\
\hline & Sancaktepe & P7; P9; P14; P17; P19; P21; P22 & & \\
\hline & Ümraniye & P1; P8; P12; P13; P16; P18; P20 & & \\
\hline & Üsküdar & P4; P8; P12; P13; P16; P18; P20 & & \\
\hline & Atașehir & P1; P8; P12; P16; P18; P20 & & \\
\hline & Beykoz & P2; P9; P14; P17; P19; P20; P21; P22 & & \\
\hline & Çekmeköy & P2; P3; P9; P13; P14; P17; P19; P21; P22 & & \\
\hline & Kadıköy & P4; P10; P12; P16; P18; P20 & & \\
\hline 9 & Kartal & P5; P10; P15; P20; P21; P22 & 358 & $0 \%$ \\
\hline & Maltepe & P6; P10; P15; P16; P18; P20; P21; P22 & & \\
\hline & Sancaktepe & P7; P9; P14; P17; P19; P21; P22 & & \\
\hline & Ümraniye & P1; P8; P12; P13; P16; P18; P20 & & \\
\hline & Üsküdar & P4; P8; P12; P13; P16; P18; P20 & & \\
\hline & Ataşehir & P1; P8; P12; P16; P18; P20 & & \\
\hline & Beykoz & P2; P9; P14; P17; P19; P20; P21; P22 & & \\
\hline & Çekmeköy & P2; P3; P9; P13; P14; P17; P19; P21; P22 & & \\
\hline & Kadıköy & P4; P10; P12; P16; P18; P20 & & \\
\hline 10 & Kartal & P5; P10; P15; P20; P21; P22 & & \\
\hline 10 & Maltepe & P6; P10; P15; P16; P18; P20; P21; P22 & 358 & $0 \%$ \\
\hline & Pendik & P5; P11; P15; P19; P21 & & \\
\hline & Sancaktepe & P7; P9; P14; P17; P19; P21; P22 & & \\
\hline & Ümraniye & P1; P8; P12; P13; P16; P18; P20 & & \\
\hline & Üsküdar & P4; P8; P12; P13; P16; P18; P20 & & \\
\hline
\end{tabular}

\section{Conclusion}

One of the main concerns of academic and practical world is about reducing the level of global warming. Due to the importance of the topic, various applications are being performed in an increasing trend. However, electric vehicles play a significant and direct role for overcoming the global warming and are the focus of this study. Specifically, the problem of determining electric charging stations' locations is handled in this study. Flow-refuelling location model is used as the solution methodology and an application is performed in the Anatolian part of Istanbul so as to maximize the total captured flow rate. The stations and paths captured by stations are obtained for different $p$ values.

The location problem of electric charging stations is handled in a classic way in this study. However, for further studies, additional constraints can be added by considering the capacity 
and type of stations. Moreover, for large-size problems, heuristic algorithms can be developed. Last but not least, multiobjective approaches can be applied considering various objectives simultaneously.

\section{References}

[1] Joint Research Centre. "Emissions Data and Maps". https://edgar.jrc.ec.europa.eu (01.07.2018).

[2] Olivier, JGJ, Schure KM, Peters JAHW. "Trends in global $\mathrm{CO} 2$ and total greenhouse gas emissions". PBL Netherlands Environmental Assessment Agency Report, 2017.

[3] Nakata T. "Analysis of the impact of plug-in hybrid vehicles on energy systems in Japan". Transportation Research: Part D, 5, 373-383, 2017.

[4] Rahman I, Vasant PM, Singh BSM, Abdullah-Al-Wadud M, Adnan N. "Review of recent trends in optimization techniques for plug-in hybrid, and electric vehicle charging infrastructures". Renewable and Sustainable Energy Reviews, 58, 1039-1047, 2016.

[5] Iwata K, Matsumoto S. "Use of plug-in hybrid vehicles in japan: an analysis of used car market data". Transportation Research, Part D, 46, 200-206, 2016.

[6] Türkiye Elektrikli ve Hibrit Araçlar Derneği. "Makaleler". http://tehad.org (01.10.2018).

[7] Gavranovic H, Barut A, Ertek G, Yüzbaşıŏlu OB, Pekpostalcı O, Tombuș Ö. "Optimizing the electric charge station network of EŞARJ". Procedia Computer Science, 31, 15-21, 2014.

[8] Awasthi A, Venkitusamy K, Padmanaban P, Selvamuthukumaran R, Blaabjerg F, Singh AK. "Optimal planning of electric vehicle charging station at the distribution system using hybrid optimization algorithm". Energy, 133, 70-78, 2017.

[9] Lee C, Han J. "Benders-and-Price approach for electric vehicle charging station location problem under probabilistic travel range". Transportation Research, Part B, 106, 130-152, 2017.

[10] Hakimi SL. "Optimum locations of switching centers and the absolute centers and medians of a graph". Operations Research, 12(3), 450-459, 1964.

[11] Hodgson MJ. "A flow-capturing location-allocation model". Geographical Analysis, 22(3), 270-279, 1990.

[12] Csonka B, Csiszár C. "Determination of charging infrastructure location for electric vehicles". Transportation Research Procedia, 27, 768-775, 2017.

[13] Chung SH, Kwon C. "Multi-period planning for electric car charging station locations: A case of Korean Expressways". European Journal of Operational Research, 242, 677-687, 2015.

[14] Xylia M, Leduc S, Patrizio P, Kraxner F, Silveria S. "Locating charging infrastructure for electric buses in Stockholm". Transportation Research, Part C, 78, 183-200, 2017.

[15] Polimeni A, Napoli G, Andaloro L, Antonucci V. "Electric vehicle charging infrastructure planning in a road network". Renewable and Sustainable Energy Reviews, 80, 98-108, 2017.
[16] Zhao H, Li N. "Optimal siting of charging stations for electric vehicles based on fuzzy delphi and hybrid multicriteria decision making approaches from an extended sustainability perspective". Energies, 9(4), 1-22, 2016.

[17] Guler D, Yomralioglu T. "GIS and fuzzy AHP based area selection for electric vehicle charging stations". ISPRS TC IV Mid-term Symposium on 3D Spatial Information Science - The Engine of Change, Delft, The Netherlands, 01-05 October 2018.

[18] Afroditi M, Boile S, Theofanis ES, Margaritis D. "Electric Vehicle Routing Problem with industry constraints: trends and insights for future research". Transportation Research Procedia, 3, 452-459, 2014.

[19] Erbas M, Kabak M, Ozceylan E. "Optimal siting of electric vehicle charging stations: A GIS-based fuzzy Multi-Criteria Decision Analysis". Energy, 163, 1017-1031, 2018.

[20] Ju Y, Ju D, Gonzalez EDRS, Giannakis M, Wang A. "Study of site selection of electric vehicle charging station based on extended GRP method under picture fuzzy environment". Computer\&Industrial Engineering, 135, 1271-1285, 2019.

[21] Liu Q, Liu J, Le W, Guo Z, He Z. "Data-driven intelligent location of public charging stations for electric vehicles". Journal of Cleaner Production, 232, 531-541, 2019.

[22] Zhang Y, Qiu Z, Gao P, Jiang S. "Location model of electric vehicle charging stations". International Conference on Physics, Mathematics and Statistics, Shanghai, China, 12-14 May 2018.

[23] Jochem P, Szimba E, Oppermann M. "How many fastcharging stations do we need along European highways?". Transportation Research, Part D, 73, 120-129, 2019.

[24] Dascioglu BG, Kalender ZT, Tuzkaya G, Kilic HS. Evaluation of Electric Vehicles Station Locations with an Extended TOPSIS Methodology Using Probabilistic Linguistic Term Sets. Editors: Kahraman C, Cebi S, Cevik Onar S, Oztaysi B, Tolga A, Sari I. Intelligent and Fuzzy Techniques in Big Data Analytics and Decision Making, 820-828, Springer, Cham, 2019.

[25] Kuby MJ, Lim S. "The flow-refueling location problem for alternative-fuel vehicles". Socio-Economic Planning Science, 39, 125-145, 2005.

[26] Kuby MJ, Lim S. "Location of alternative-fuel stations using the Flow-Refueling Location Model and dispersion of candidate sites on arcs". Network and Spatial Economics, $7(2), 129-152,2007$.

[27] Kuby MJ, Lines L, Schultz R, Xie Z, Kim JG, Lim S. "Optimization of hydrogen stations in Florida using the flow-refueling location model". International Journal of Hydrogen Energy, 34, 6045-6064, 2009.

[28] General Directorate for Highways department. "İstatistikler". https://www.kgm.gov.tr/. 